\title{
ArcheoSciences
}

Revue d'archéométrie

\section{Archaeological and geophysical survey in deserted early islamic village Al-Qusur (Failaka, Kuwait)}

K. Pieta, A. H. Shehab Shehab, J. Tirpák, M. Bielich and M. Bartík

\section{(2) OpenEdition}

Electronic version

URL: https://journals.openedition.org/archeosciences/1491

DOI: 10.4000/archeosciences. 1491

ISBN: 978-2-7535-1599-4

ISSN: 2104-3728

Publisher

Presses universitaires de Rennes

\section{Printed version}

Date of publication: 30 October 2009

Number of pages: $155-157$

ISBN: 978-2-7535-0943-6

ISSN: 1960-1360

\section{Electronic reference}

K. Pieta, A. H. Shehab Shehab, J. Tirpák, M. Bielich and M. Bartík, "Archaeological and geophysical survey in deserted early islamic village Al-Qusur (Failaka, Kuwait)", ArcheoSciences [Online], 33 (suppl.) 2009, Online since 30 October 2011, connection on 01 February 2022. URL: http://

journals.openedition.org/archeosciences/1491 ; DOI: https://doi.org/10.4000/archeosciences.1491 


\title{
Archaeological and geophysical survey in deserted early islamic village Al-Qusur (Failaka, Kuwait)
}

\author{
K. Pieta*, A. H. Shehab Shehab*, J. Tirpák*, M. Bielich* and M. Bartík*
}

Key words: Ground Penetrating Radar, archaeological excavations, settlement units, Early Middle Ages $\left(6^{\text {th }}-8^{\text {th }}\right.$ cent.AD), Failaka Island, Kuwait.

Failaka Island, the second largest and the only inhabited offshore island of Kuwait, is situated $17 \mathrm{~km}$ east of Kuwait mainland, in the entrance to Kuwait Bay. They can be found along the shores and approximately in the middle of the island and correspond with occurrence of known archaeological sites.

Failaka's history goes back to the Bronze Age Dilmun civilization. After the decline of the occupation during the Middle Bronze Age, Failaka was again inhabited during Seleucid and post-Seleucid periods when a fort and a temple were established there. During that time Failaka was known as Ikaros.

The most important representative of this time on the island is the investigated site on Al-Qusur. Textual records indicate very clearly the presence of monks, churches and Christian communities in the Gulf from the $4^{\text {th }}-5^{\text {th }}$ cent. $\mathrm{AD}$ or earlier which has not been confirmed by the archaeological records, yet. The archaeological evidences show that period of active church building actually followed the disappearance of Bet Qatraye and its bishops from the texts in $676 \mathrm{AD}$, that churches were established even thereafter and that "Christianity in the region persisted until at least the late ninth century" (Carter, 2008). The eighth and ninth century are sometimes even referred to as the Golden Age of the Church of the East (Baumer, 2006).

\section{AL-QUSUR SITE AND HISTORY OF RESEARCH}

Al-Qusur is an area in the middle of the island of Failaka and belongs to one of its elevated spots with highest altitude ca. above mean sea level (AMSL) and the lowest one $2 \mathrm{~m}$. The area of around 2 by $2.6 \mathrm{~km}$ covered by archaeological remains is surrounded from east and west by marshes and has easiest access to the shore and to the sea from the north and south. The archaeological remains (foundations of courtyard houses, fenced farmsteads and isolated smaller structures) were first recorded by aerial prospecting in 1960. The site was first surveyed and excavated by the Italian mission in the mid 1970s (Patitucci and Uggeri, 1984). In the late 1980s and in 1999 the KuwaitiFrench and French missions were active here (Callot and Calvet, 1999). Kuwaiti-Slovak Archaeological Mission (further KSAM) began its activities in 2006. Apart from field walking and excavation, the geophysical methods were employed at the site. The French Mission linked up to previous research since 2007.

General plan of the site created in 1970s by the Italian team does not display all the structures and courtyard houses on the site as it was proved by survey of KSAM in 2006 and 2007. At the moment, over 140 settlement units can be found at

* Archaeological Institute SAS 
Al-Qusur when combining the outputs of aerial photographing in 1960, and results of Italian and Kuwaiti-Slovak teams.

Dating of the site varies between $5^{\text {th }}-6^{\text {th }}$ and $9^{\text {th }}-10^{\text {th }}$ cent. AD (Umayyad and Early Abbasid dynasties; see Patitucci and Uggeri [1984], p. 160; Carter [2008], p. 92, 97, although recently the dates were narrowed between mid $8^{\text {th }}$ and early $9^{\text {th }}$ cent. AD [Kennet, 2007]).

\section{GROUND PENETRATING RADAR SURVEY OF COURTYARD HOUSE 1}

The GPR survey of the courtyard house 1 was carried out twice - in 2006 and in 2008 (Fig. 1). In 2006 the data were collected along the profiles with N-S orientation on the area 50 by $50 \mathrm{~m}$ (Pieta/Shehab/Tirpák/Bielich/Bartík/Ďuriš 2007) and in 2008 along E-W oriented profiles on the area 60 by $70 \mathrm{~m}$. The GPR data were acquired using RAMAC X3M (Geoscience Malå, Sweden) equipped with $500 \mathrm{MHz}$ shielded antenna. At the selected area the data were collected within parallel grids with mutual distance of lines $0.50 \mathrm{~m}$, in a step mode $0.02 \mathrm{~m}$, and depth (time window) $60 \mathrm{~ns}$. The horizontal time slices for the depths $0.3-0.4 \mathrm{~m}$ from the investigated area (Fig. 2A) clearly show the anomalies caused by the foundations of a courtyard house partially visible also on the surface.

\section{EXCAVATION OF COURTYARD 1}

In year 2008 we excavated courtyard 1 (by Slovak 1, 81 by Italian team). The foundations were very well preserved, small parts of fence was destroyed. The entrance was dis-

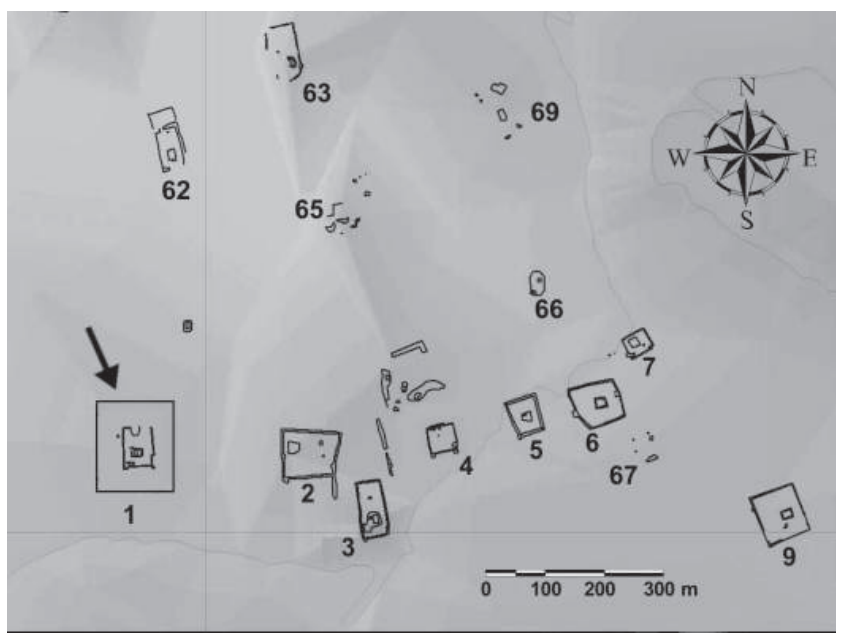

Figure 1: Al-Qusur. Part of the geodetic plan with houses

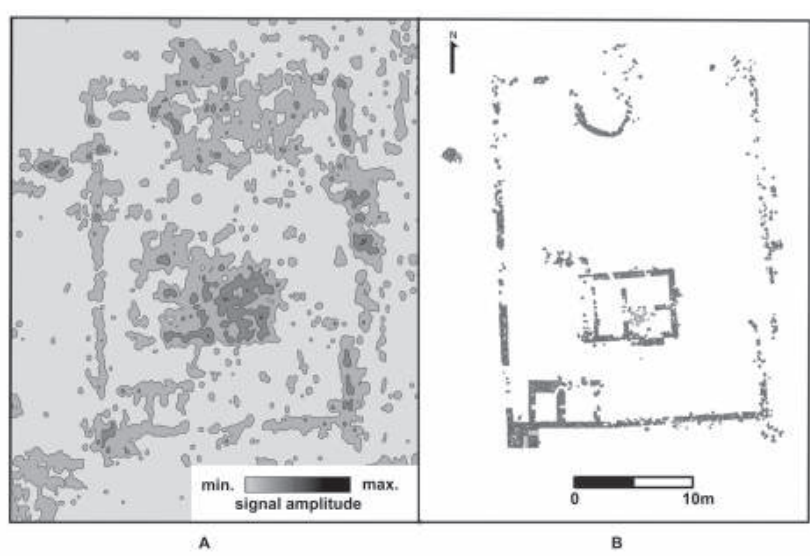

Figure 2: Al-Qusur. GPR horizontal slice for depth 30-40 cm (A) and plan of excavated architecture (B)

covered in N-W- corner. The walls were $50 \mathrm{~cm}$ wide. In the $\mathrm{S}-\mathrm{W}$ corner, there were small outbuildings. In total, $640 \mathrm{~m}^{2}$ (in 25 trenches and 5 deep soundings) was uncovered and the following structures were documented: central house (central building), courtyard fence, two outbuildings (one outside and one inside the fence), ditch, and an oval structure (of later date) (Fig. 2B and Fig. 3). The extent of the excavations almost always reached the bedrock. By surface prospecting were found pottery and glass vessel fragments, as well as some other small finds found. Generally, 13 fragments from recognized glass vessels and many other glass splinters were discovered.

The results of the excavation showed no record of rebuilding of the house 1. In our opinion, it is a standard type of early medieval courtyard house, typical for Al-Qusur site. The oval feature in northern part of fence is, secondarily built on the ruins of the courtyard. KSAM is intending to continue its activities on Al-Qusur.

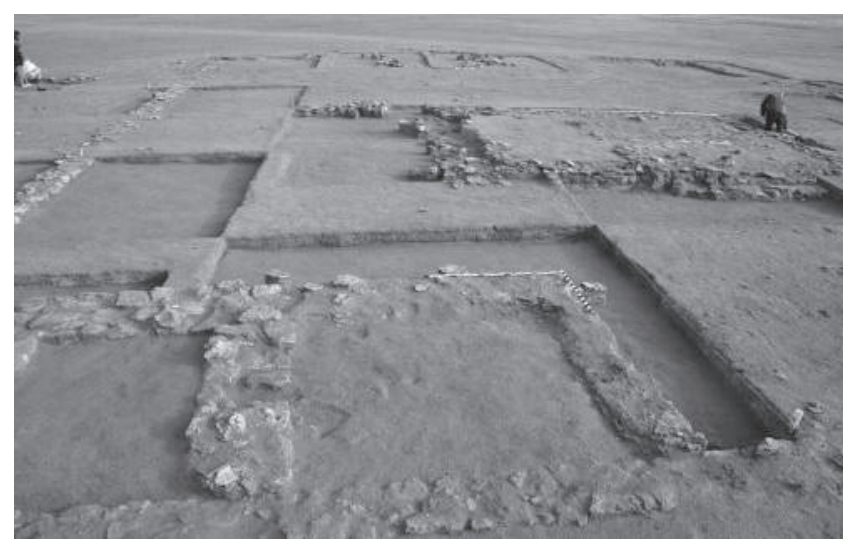

Figure 3: Al-Qusur. Photo from excavation in 2008 


\section{References}

Baumer, C., 2006. The Church of the East. An illustrated history of Assyrian Christianity. London \& New York.

Callot, O., Calvet, Y., 1999. Preliminary report on the topographical mission at Failaka. Unpublished report, Kuwait.

Carter, R., 2008. Christianity in the Gulf during the first centuries of Islam. Arabian Archaeology and Epigraphy, 19: 71-108.
KenNeT, D., 2007. The decline of eastern Arabia in the Sasanian period. Arabian Archaeology and Epigraphy, 18: 86-122.

Patitucci, S., Uggeri, G., 1984. Failakah. Insediamenti Islamici. Ricerche e Scavi nel Kuwait. Rome.

Pieta, K., Shehab, S. A. H., Tirpák, J., Bielich, M., BartíK, M., Ďuriš, J., 2007. Archaeological and Geophysical Prospecting of Deserted Early Islamic Village Al-Qusur (Failaka Island, State Kuwait). Študijné zvesti Archeologického ústavu, SAV 41: 74-76. 